\title{
Crop
Reports
}

\section{Goldenrod: Plants with Multipurpose potential}

\author{
Rhoda L. Burrows
}

Additional INDEX WORDs. solidago, perennial, cut flower, solidaster

S pecies of Solidago are lowmaintenance herbaceous pe rennials commonly known as goldenrod in North America and as solidago in other parts of the world as well as in the floriculture trade. These summer- and fall-flowering plants have been widely used in Europe, but are currently underused in North America, their continent of origin. Goldenrod are primarily used as landscaping plants in the United States, but are gaining popularity for use in the floral trade as cut flowers or potted plants. Cut stems are heavily traded in floral auctions in $\mathrm{Eu}-$ rope for use as filler flowers, with numbers sold steadily increasing over the last several years (Pathfast Publishing, 1999). Most goldenrod species tolerate heat, drought, and cold, ranging in cold hardiness from Zones 2-9 (Dole and Wilkins, 1999), although several species are adapted instead to moderate shade or moist soils. It is an unfortunate myth that goldenrod are a major cause of hayfever; in fact, they are insect-pollinated (Gross and Werner, 1983) and the pollen is too large and sticky to be carried far on the wind (Semple et al., 1999).

Horticulture, Forestry, Landscape, and Parks Department, Box 2140A, South Dakota State University, Brookings, SD 57007.

\section{Classification}

All goldenrod species are members of the Aster tribe of the Asteraceae (Compositae), a large family with 20,000 species found primarily in temperate regions. Other well-known ornamental genera in the Asteraceae include Chrysanthemum, Cosmos, Dahlia, Echinacea (coneflower), Erigeron (daisy), Helianthus (sunflower), Tagetes (marigold), and Zinnia (Liberty Hyde Bailey Hortorium, 1976). The Aster tribe includes more than 100 genera, mostly perennial or sometimes annual herbs, with a few shrubs (Liberty Hyde Bailey Hortorium, 1976). About 130 goldenrod species exist, with numerous cultivated varieties and hybrids. Identification to species can sometimes be quite difficult, as hybridization within the genus is common, and plant characteristics, even within a given species, may be quite variable.

Aster species are closely related, and an apparent bigeneric hybrid between aster and goldenrod (solidago), solidaster (Solidaster luteus) was found in Lyon, France in 1910. This plant was described as a chance seedling of upland aster (Asterptarmicoides), probably hybridized with an undetermined solidago species (Dress, 1979). Canadian goldenrod ( $S$. canadensis) is the most likely parent, although others have been suggested. Some authorities assert that upland aster is more closely related to goldenrod than to other aster species; if so, solidaster is actually a hybrid within solidago, rather than between genera (Dress, 1979). Regardless of its classification, solidaster is now widely available as a cut flower year-round, and is valued for its yellow flowers in mixed bouquets as well as in perennial beds.

\section{Botanical description}

Goldenrod are herbaceous perennials, with plant heights ranging from 2.5 to 80 inches $(5$ to $200 \mathrm{~cm}$ ), depending on species (Semple, 2001). Stems are usually unbranched, arising from short rhizomes or root crowns. Leaves are alternate, simple, entire to toothed, and range in color from grey-green to dark-green. Flowers are most commonly golden-yellow (Fig. 1), although one species, silverrod (S. bicolor) has cream to white flowers. Flower heads consist of pistillate ray and perfect disc flowers aggregated into racemes, corymbs, spikes, umbels or panicles (Fig. 2) (Liberty Hyde Bailey Hortorium, 1976). All goldenrod species have a chromosome base number of $x=9$, and many include several different ploidy levels (Semple, 2001). Goldenrod species are mostly self-incompatible, and are insect-pollinated (Gross and Werner, 1983.)

\section{Origin and development}

Most goldenrod species are native to North America, with a few also native to Europe, Asia, the Azores, and South America (Liberty Hyde Bailey Hortorium, 1976). Populations of four goldenrods [Short's goldenrod $(S$. shortii), Blue ridge goldenrod ( $S$.

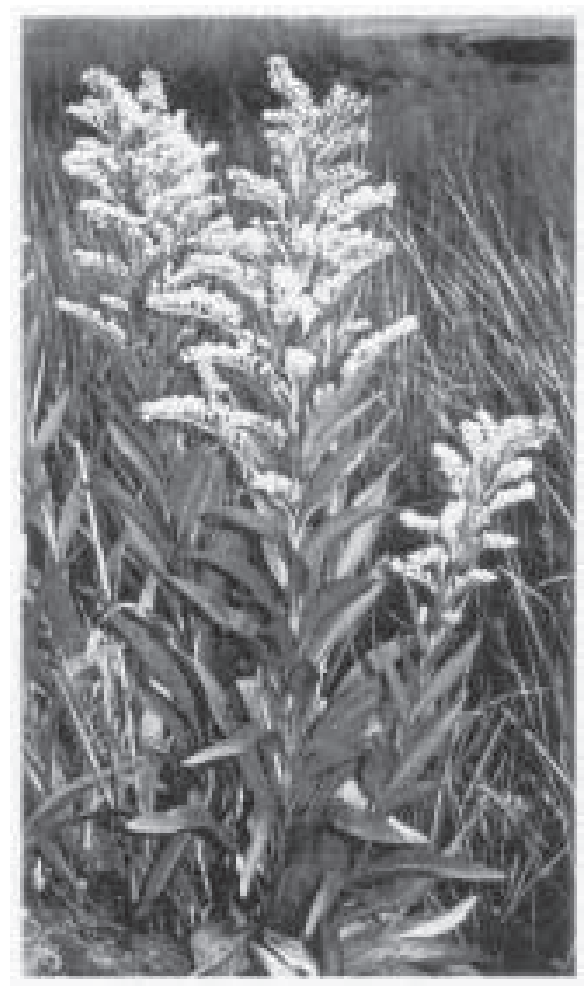

Fig. 1. Seaside goldenrod (Solidago sempervirens) panicle (photo compliments of John C. Semple). 


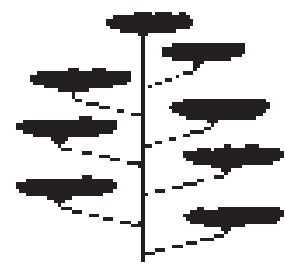

Racente

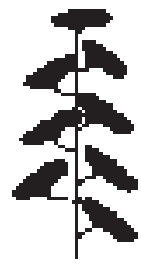

Spike

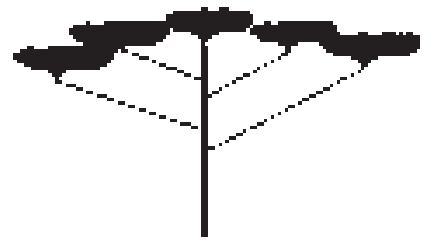

Corymb

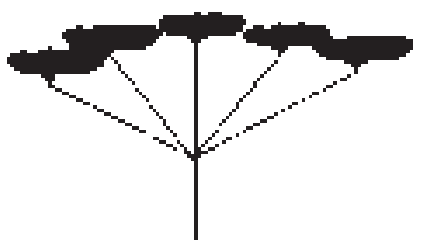

Umbel

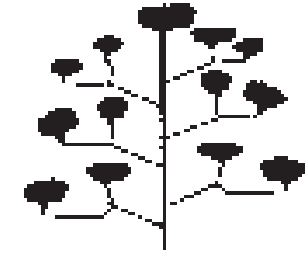

Panicle

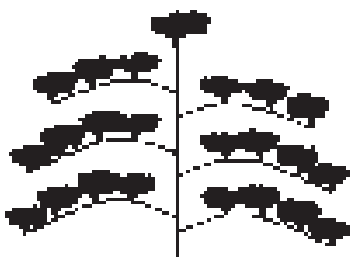

Arching Panicle
Fig. 2. Common flower types of goldenrod species.

spithamea), Houghton's goldenrod ( $S$. houghtonii), and white-haired golden$\operatorname{rod}(S$. albopilosa)] are currently listed by the U.S. government as threatened or endangered (U.S. Fish and Wildlife Service, 1985a, 1985b, 1985c, 1988).

Europeans were quick to appreciate the ornamental qualities of the goldenrod species that were sent back from the new world. Already by 1741, a European horticulturist had described 30 species or subspecies of goldenrod (known then as Virga Aurea), commenting:

"The seventeen first mentioned are the most valuable sorts which I have

Table 1. Characteristics of selected common species or cultivars of goldenrod (Solidago) (Armitage, 1993; Brickell and Zuk, 1997; Hawkes, 2000; Missouri Botanic Garden, 2000).

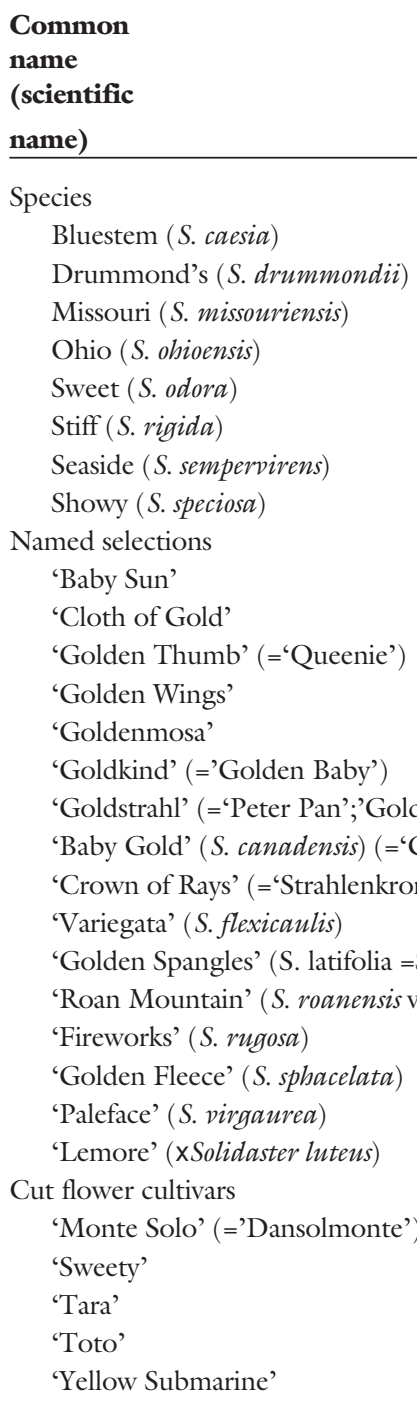

\begin{tabular}{|c|c|}
\hline $\begin{array}{c}\mathbf{H t} \\
\text { (inches) }^{z}\end{array}$ & Inflorescence \\
\hline
\end{tabular}

Coldhardiness Flowering zone season $^{\mathrm{y}}$

Axillary panicle

Panicle

Compact panicle

Flattened corymb

Flat panicle

Dense umbel

Dense 1-sided raceme

Cylindrical panicle

24-72

12-24

18

12

48-60

30

18-24

24-36

24-30

24-36

54

24-30

18-24

$36-48$

18

24

24-36

24-36

12-14

$36-48$

36

24-36
Raceme

Open raceme

Panicle

Corymb-like panicle (branched)

Conical panicles

Horizontal panicles

Dense panicle

Raceme

Dense panicle

Axillary panicle

Raceme

Loose spike

Curved narrow horizontal panicle

Dense panicle

Upright spike

Raceme

Panicle

Upright panicle

Panicle

Panicle

Arching panicle

\section{LSu-F}

5-8 LSu-EF

3-6

5-9

3-9

3-9

3-9

3-9

4-9

4-9

$-\cdot-$

5-9

6-9

4-9

6-9

4-8

5-9

4-9

3-9

6-8

5-9

3-9

5-9

6-7

$\mathrm{MSu}$

LSu

MSu-EF

LSu-EF

EF-LF

LSu-EF

MSu

LSu

LSu

LSu-EF

LSu

MSu-LS

LSu-F

ESu-F

$\mathrm{MSu}-\mathrm{F}$

ESu-F

EF

LSu-EF

LSu,EF

EF-LF

$\mathrm{MSu}$

LSu-EF

EF

MSu-LSu Disease
resistance
Mildew Rust

${ }^{\mathrm{z}} 1$ inch $=2.54 \mathrm{~cm}$.

${ }^{\mathrm{y}} \mathrm{ESu}=$ early summer; $\mathrm{MSu}=$ midsummer; $\mathrm{LSu}=$ late summer; $\mathrm{EF}=$ early fall; $\mathrm{F}=$ fall.

${ }^{x} \mathrm{~S}=$ susceptible; $\mathrm{MS}$ = moderately susceptible; $\mathrm{MR}=$ moderately resistant; $\mathrm{R}=$ resistant; Mildew = powdery mildew.

${ }^{\mathrm{w}}$ No information available. 
yet seen in the English Gardens; the greatest part of which are natives of America, from whence, it is very probable, there may be many other sorts brought.... These plants are very great ornaments in the borders of large flowergardens, where, by their succession of flowering, they afford a very great pleasure.... and their flowers being produced, for the most part, on long specious spikes or panicles, do make a very handsome appearance, and are very ornamental to flowerpots..." (Miller, 1741).

Not all the species were equally appreciated. Miller (1741) goes on to describe an imported species he calls to its aggressive nature, had already escaped cultivation to become a common weed in England. Other species Annual Virginian Goldenrod, that, due [e.g., tall goldenrod ( $S$. altissima) and late goldenrod ( $S$. gigantea)] are also aggressive invaders in Europe.

Today numerous cultivars and hybrids exist, ranging in size from low growing types used for perennial beds to taller types used for cut flowers as well as landscaping (Table 1). Although various cultivars have been used for cut flowers, recently hybrids have been specifically developed for the floriculture industry [Golden Line series: 'Monte Solo', 'Monte D'Oro', and 'Golden Gate' by Danziger (Beit Dagan, Israel); and 'Yellow Submarine' and 'Tara,' by Bartels Stek (Aalsmeer, The Netherlands)]. 'Sweety,' also from Bartels Stek, is a dwarf goldenrod developed for container use.

The Chicago Botanic Gardens (USDA Hardiness Zone 5b) evaluated
25 goldenrod species and hybrids for use in midwestern United States gardens (Hawkes, 2000) on the basis of ornamental traits, hardiness, and pest and disease resistance. 'Fireworks', a selection of rough-stemmed goldenrod (S. rugosa) introduced from North Carolina in 1993, was named best overall for both floral and plant form characteristics, as well as disease resistance. Other selections that did well in the Chicago trial included 'Baby Sun,' an early-season (midsummer) bloomer; variegated zigzag goldenrod (S. flexicaulis 'Variegata'), with gold-mottled leaves; 'Goldkind' (='Golden Baby'), also used for cutflowers; and 'Golden Fleece', a lateseason blooming selection of dwarf goldenrod (S.spacelata) with heart-shapedbasal leaves. 'Peter Pan' (='Goldstrahl'), a popular cultivar elsewhere with good disease resistance, was not winter hardy in the Chicago trial but may do very well under milder conditions. Several cultivars appear to be more popular in Europe than the United States, including the diminutive 'Golden Thumb'(='Queenie'), and 'Golden Wings'.

With the exception of the Noninvasive; large individual flowers in clusters Forms loose colonies; tolerates light shade Disease-free foliage; does well in rich soils

Anise-scented leaves; medicinal

Rhizomaceous; few leaves on stem Coastal species; can be used to stabilize dunes Plants form tight clumps; non-aggressive

Similar to 'Goldkind'

Pale yellow (European)

Choice dwarf; yellowish-green foliage; European

Older European hybrid; similar to S. canadensis

May tend to lodge; leaves brown under stress

Long bloom season; Cut flower; Clump-forming

Bright yellow; strong stems

US hybrid; sometimes used as cut flower

Pale yellow; stiff columnar plant; cut flower; lacy foliage; not an aggressive spreader

Gold-mottled leaves; flowers borne in axils; tolerates partial shade

Gold mottled dark-green leaves; rhizomaceous; some sources list as S. flexicaulis

No nectar; introduction from NC Botanical Garden; good disease resistance; compact clump habit Dense mat of semi-evergreen heart-shaped basal leaves; 1980s introduction from Mt. Cuba Center, Delaware Pale-yellow; European

Pale-yellow color fades to white or cream; tolerates partial shade

Bred for cut flower; also good landscape plant

Pot plant

Cut flower filler

Flowers 2 weeks before 'Yellow Submarine'

Used for cut flowers; flowers 2 weeks before 'Tara' newer cut flower cultivars, little effort has been made to breed goldenrod for specific uses; most existent cultivars are chance selections, and mostly of unknown parentage. Because most goldenrod outcross readily, selections must either be well isolated from other goldenrod during seed production or be propagated vegetatively. Perhaps due in part to their multiple ploidy level as well as their tendency to outcross, development of a stable new cultivar for seed propagation can be quite difficult (R. Sterkel, personal communication).

\section{Uses}

Numerous goldenrod species are used as ornamental perennials in the landscape. Because the rhizomaceous species can spread aggressively, clump-forming species or selections are preferred for use in perennial beds. Certain species or ecotypes [e.g., canadian goldenrod ( $S$. canadenesis)] may be allelopathic to nearby plants (Fisher et al., 1978). Selected cultivars and hybrids are used in the cut flower industry and a small market exists 
for medicinal uses, particularly for european goldenrod ( $S$. virgaurea). The cut flowers of many species can also be used in dried arrangements.

Goldenrods have been used for tea and medicines by native Americans and others, for ailments ranging from respiratory to urinary and kidney disorders, and hemorrhoids (Coffey, 1993; Larson and Johnson, 1999). All species are thought to contain the active components saponins, quercetin, flavonoids, tannin and an essential oil (Kaye and Billington, 1997). The Physician Desk Reference for Herbal Medicines (PDR) (Fleming, 2000) lists canadian goldenrod (also called woundwort) as a diuretic and lists a number of compounds found in the plant, including caffeic acid derivatives (including chlorogenic acid). The PDR warns against confusing european goldenrod with canadian goldenrod; preparations of both are sold in some herbal markets for use as a diuretic and an astringent and are said to help remove kidney stones. The German E Commission, a governmental committee charged with evaluating the safety and efficacy of over 350 medicinal herbs and herbal preparations sold in Germany, reported approved use of goldenrods for a variety of urinary conditions, as the preparations were deemed both safe and effective (Blumenthal, 1998). However, Skidmore-Roth (2001) warns that european goldenrod can induce abortions and lists a number of additional serious side-effects.

\section{Seed and propagation}

Goldenrod can be grown from seed, sometimes flowering in the first year, but usually not until the second year after sowing. Some species, such as columnar goldenrod ( $S$. petiolaris) require up to 10 weeks stratification at $40^{\circ} \mathrm{F}(4$ $\left.{ }^{\circ} \mathrm{C}\right)$ (Bratcher, et al. 1993); while others germinate readily in 2 to 3 weeks at 68 to $72{ }^{\circ} \mathrm{F}\left(20\right.$ to $22{ }^{\circ} \mathrm{C}$ ) (Armitage, 1993). For potted plant production, Nau (1999) recommends sowing seed during late spring or early summer, with plants overwintered for sale the followingyear. Alternately, salable 32-cell transplants of 'Golden Baby' with 50\% to $75 \%$ bloom the first year can be produced in 10 to 12 weeks by seeding in January or February, assuming germination temperature of $70{ }^{\circ} \mathrm{F}\left(21^{\circ} \mathrm{C}\right)$ and subsequent temperatures of 50 to $55^{\circ} \mathrm{F}$ (10 to $\left.13{ }^{\circ} \mathrm{C}\right)$ (Nau, 1999).

Vegetative propagation is used for cultivars that do not come true from seed, including solidaster. Stem tip cuttings can be taken in late spring to early summer from vegetative shoots (Phillips, 1985). If plants are grown from liners or plugs rather than seed, production time for perennial plant sales can be reduced to 8 to 13 weeks (Dole and Wilkins, 1999). Species that spread by rhizomes may be divided in the spring or fall, every 2 to 3 years, with up to 40 divisions per plant (Dole and Wilkins, 1999; Phillips, 1985). The rhizomes should be replanted with the tops about 1 inch $(2.5 \mathrm{~cm})$ below the media surface.

\section{Cultivation}

Field-grown goldenrod should be cut back to the ground in late fall or early spring. Generally, plants flower in the late summer to autumn, although in the most southern areas of the United States, spring flowering sometimes occurs. Field spacing of $1 \times$ $1 \mathrm{ft}(0.3 \mathrm{~m})$ or $1 \times 1.5 \mathrm{ft}(0.3 \times 0.5 \mathrm{~m})$ is recommended (Armitage 1993), with replanting every 2 to 3 years to maintain highest quality.

Plants can be grown under cover at a density of 1.5 to 2 cuttings $/ \mathrm{ft}^{2}(0.13$ to 0.19 cuttings $\left./ \mathrm{m}^{2}\right)$ (McGrew, 1998). Temperatures of 55 to $65^{\circ} \mathrm{F}$ (13 to 18 $\left.{ }^{\circ} \mathrm{C}\right)$ night and 70 to $80^{\circ} \mathrm{F}\left(21\right.$ to $\left.27^{\circ} \mathrm{C}\right)$ day are recommended for the vegetative (LD) phase of growth (Dole and Wilkins, 1999). Two to 3 weeks after planting cuttings, they can be pinched back to 3 or 4 sets of leaves, but this is optional for most cultivars. Pinching is recommended for 'Sweety' 2 weeks after planting, with an optional second pinch at 5 weeks. Daminozide (B-Nine, Uniroyal Chemical Co., Middlebury, Conn.) can be applied if necessary for further height control(Grolink, 2001). Long days (>16 h) should be maintained during the vegetative phase, about 5 to 8 weeks. Supplemental lighting of a minimum of $1.35 \mathrm{~W} / \mathrm{ft}^{2}\left(15 \mathrm{~W} \cdot \mathrm{m}^{-2}\right)$ is recommended. Once the plants reach 18 inches (46 $\mathrm{cm}$ ), short days can be applied to begin bud initiation, and night temperatures should be raised to 62 to $65^{\circ} \mathrm{F}$ ( 17 to 18 ${ }^{\circ} \mathrm{C}$ ) to encourage bud set (McGrew, 1998). The flowers will be ready for harvest about 10 weeks after planting; pinching will delay harvest about 2 weeks. Most growers can obtain 3 to 5 successive cycles of flowering in the greenhouse from each planting. After each flush, all flowering stems should be cut back completely to the ground, leaving no old tissue. This removal will stimulate new buds from the rhizomes, which will develop into quality stems for the next cycle of flowering.

\section{Soil, nutrition, and irrigation}

Goldenrod can flourish in a wide range of soils. In general, a well-drained media with a pH of 5.5 to 6.5 is suitable for container production, and $\mathrm{pH}$ of 5.0 to 7.0 is acceptable for field production. Plants are sensitive to high media salts; electrical conductivity levels should be kept at 0.75 to $1.5 \mathrm{dS} \cdot \mathrm{m}^{-1}$ (based on a 1 medium : 2 water dilution) (McGrew, 1998). Seedlings and container-grown plants can be fertilized with 50 to 100 ppm $\left(\mathrm{mg} \cdot \mathrm{L}^{-1}\right)$ of nitrogen $(\mathrm{N})$ constant liquid fertilization (Dole and Wilkins, 1999), with $\mathrm{N}$ reduced during flower bud initiation (McGrew, 1998). Field experiments have shown that different goldenrod species respond differently to increased N levels (Pratt, 1984), so optimal levels need to be adjusted according to the particular cultivar or selection grown.

Most goldenrod are highly drought tolerant once established, but optimal growth will be obtained with irrigation during dry periods (Dole and Wilkins, 1999). Seedlings and container grown plants should be kept slightly moist; too much water will cause excessive side shoot growth. To help initiate bud set, the soil should be allowed to dry gradually. Slight wilting of the leaves between waterings is acceptable once buds are set (McGrew, 1998).

\section{Disease and insect control}

Goldenrod are susceptible to several fungal foliar diseases, including powdery mildew (Erysiphespp., Sphaerotheca spp.), rust (Coleosporium spp., Puccinia spp., Uromyces spp.), downy mildew (Basidiophora entospora, Plasmopara halstedii), and various leaf spots (Ascochyta compositarum, Asteroma solidaginis, Cercospora parvimaculans, Collectotrichum spp., Septoria spp.) (Armitage, 1993; Horst, 1990). Some cultivars show some resistance to one or more of these diseases (see Table 1). Pots or individual plants should be spaced to allow air to circulate freely to help minimize diseases both in the greenhouse and outdoors. In the greenhouse, careful watering is needed to avoid damping-off and root rots. Pines (Pinusspp.) are alternate hosts for some of the rusts, so field plantings should not be located near these conifers (Armitage, 1993). A 
limited number of fungicides, some recently registered, are available for use in production greenhouses and nurseries as well as landscape use.

Leaf miner, whitefly, aphids, thrips, and spider mites (species not reported) can be problems in greenhouse production (Dole and Wilkins, 1999). Outdoors, a number of moth and butterfly larvae may feed on the foliage, and stem gall fly (Eurosta solidaginis) causes galls on several species (Abrahamson, 2000).

\section{Flowering}

Goldenrod species that flower late in the growing season tend to have shorter flowering periods and fewer flowers per rhizome than those that flower in middle tolate summer(Hurlbert, 1970). At least in canadian goldenrod, days to flowering is controlled more by genetics than by environmental factors such as moisture level, plant size, or plant competition (Pors and Werner, 1989). Removing senesced flowers generally encourages additional bloom.

Most species are considered shortday (SD) plants (Allard and Garner, 1940), but two [(rough-stemmed goldenrod and a selection of seaside goldenrod ( $S$. sempervirens)] are known to be long-day plants and others [early goldenrod ( $S$. juncea), elm-leaved golden$\operatorname{rod}(S$. ulmifolia), and a different selection of seaside goldenrod] are intermediate (Schwabe, 1986). While SD (14 h) is required for floral induction of canadian goldenrod, extended periods of SD were found to induce dormancy, and the shorter the daylength the more rapid the onset of dormancy. In fact, under 8-h days, the plants became dormant so quickly that flowering did not occur (Schwabe, 1986).

To force SD goldenrod in the greenhouse without inducing dormancy, a daylength of 12 to $14 \mathrm{~h}$ should be maintained for 4 to 5 weeks (Dole and Wilkins, 1999; McGrew, 1998). If light levels are too low, flower bud abortion can occur. Night temperatures should be raised to 60 to $65^{\circ} \mathrm{F}$ ( 16 to 18 ${ }^{\circ} \mathrm{C}$ ) to obtain optimal bud set (McGrew, 1998). Once buds begin to show color, the plants should be switched back to long days to prevent dormancy.

Flower height may be controlled with growth regulators such as daminozide (5000 ppm B-Nine; Uniroyal Chemical Co., Middlebury, Conn.) or paclobutrazol (80 to 100 ppm spray or 30 ppm drench Bonzi, Uniroyal Chemical Co.) (Latimer,
2002), although height control is generally not required. Most goldenrod grown for cut flower production will need netting for support (Dole and Wilkins, 1999).

For cut flower use, harvest goldenrod when half of the florets are open (Armitage, 1993). Cut flowers may be stored at 36 to $41^{\circ} \mathrm{F}\left(2\right.$ to $5^{\circ} \mathrm{C}$ ) for up to $5 \mathrm{~d}$; in water, flowers last 5 to $10 \mathrm{~d}$ (Armitage, 1993; Philosoph-Hadas et al., 1996). The Flower Council of Holland recommends storing solidaster at about $46{ }^{\circ} \mathrm{F}\left(8{ }^{\circ} \mathrm{C}\right)$. Both goldenrod and solidaster can be dried for floral arrangements (Hoogasian, 1989).

Pulsing the cut flowers with 32 ppm $(0.2 \mathrm{~mm})$ silver thiosulphate (STS $)$ or $10 \mathrm{ppm}(0.045 \mathrm{~mm})$ benzyladenine (BA) with surfactants may help delay the rapid leaf yellowing to which goldenrod are prone (Philosoph-Hadas et al., 1996). Vase life can also be extended by STS or BA treatment, or a combination of both (Philosoph-Hadas et al., 1996). Similar treatments may also be used for solidaster.

\section{Marketing}

A significant portion of the goldenrod (marketed as solidago) on the European cut-flower market are imported from sub-Saharan Africa [260 tons (236 t) from Kenya alone in 1998; Thoen et al., 2002], and goldenrod are Israel's second most important flower export after roses (Rosaspp.), according to Israel's Production Marketing Board of Ornamental Plants (Vromen, 1998). Cut flowers of both goldenrod and solidaster have a steady wholesale market in United States, with some imported from South America to meet demand (USDA, 2002).

Goldenrod are finally gaining the international attention they have long merited for use as cut flowers as well as drought-tolerant landscape perennials. Perhaps because these plants hybridize so readily, most of the available cultivars on the market are selections of unknown origin. With the exception of the cut flower industry, scant effort has been directed toward using the vast array of goldenrod germplasm in directed breeding programs. Potential exists for improving disease resistance, flower form and intensity, plant architecture, winterhardiness, and vigor. These adaptable golden treasures should have a vibrant future as cut flowers or containerized and perennial bedding plants.

\section{Literature cited}

Abrahamson, W. 2000. The solidago gall homepage. Bucknell Univ., Lewisburg, Pa. 19 May 2002. <http://www.facstaff. bucknell.edu/abrahmsn/solidago / main.html

Allard, H.A. and W.W. Garner. 1940. Further observations on the response of various species of plants to length of day. USDA Tech. Bul. 727.

Armitage, A.M. 1993. Solidago hybrids, p. 235-238. In: Specialty cut flowers. Varsity Press/Timber Press, Portland, Ore.

Blumenthal, M. 1998. The complete German Commission E monographs: Therapeutic guide to herbal medicines. Amer. Bot. Council, Austin, Texas.

Bratcher, C.B., J.M. Dole, and J.C. Cole. 1993. Stratification improves seed germination of five native wildflower species. HortScience 28:899:901.

Brickell, C. and J.D. Zuk. 1997. The American Horticultural Society A-Z encyclopedia of garden plants. DK Publishing, New York.

Coffey, T. 1993. The history and folklore of North American wildflowers. Houghton Miflin, N.Y.

Dole, J.M. and H.F. Wilkins. 1999. Floriculture: Principles and species. PrenticeHall, Upper Saddle River, N.J.

Dress, W.J. 1979. Sidelights on XSolidaster [Compositae]. Baileya 20(4):162-165.

Fisher, R.F., R.A. Woods, and M.R. Glavicic. 1978. Allelopathic effects of goldenrod (Solidago canadensis) and aster (Aster novaangliae) on young sugar maple (Acer saccharum). Can. J. For. Res. 8(1):1-9.

Fleming, T. 2000. Physicians' desk reference for herbal medicines. Medical Economics Company, Montvale, N.J.

Grolink. 2001. Solidago Sweety. GroLink Specialties, Oxnard, Calif. 14 May 2002. <http://www.grolinkspecialties.com/ sweetygrowinfo.htm>

Gross, R.S. and P.A. Werner. 1983. Relationships among flowering phenology, insect visitors, and seed-set of individuals: Experimental studies on four co-occurring species of goldenrod (Solidago: Compositae). Ecol. Monogr. 53(1):95-117.

Hawkes, R. 2000. An evaluation report of goldenrods for the garden. Plant Eval. Notes 15. Chicago Bot. Garden, Glencoe, Ill.

Hoogasian, C. 1989. In season: Solidaster. Florist 22(11):10.

Horst, R.K. 1990. Wescott's plant disease handbook. $5^{\text {th }}$ ed. Van Nostrand Reinhold, New York. 
Hurlbert, S.H. 1970. Flower number, flowering time, and reproductive isolation among ten species of Solidago(Compositae). Torrey Bot. Club. Bul. 97(4):189-195.

Kaye, C. and N. Billington. 1997. Medicinal plants of the heartland. Cache River Press, Vienna, Ill.

Larson, G.E. and J.R. Johnson. 1999. Plants of the Black Hills and Bear Lodge Mountains. S.D. State Univ., Brookings, Agr. Commun. B732.

Latimer, J.G. 2002. Selecting and using plant growth regulators on floriculture crops. Va. Polytech. Inst. 14 May 2002. <http:// www.ext.vt.edu/pubs/greenhouse/430102/430-102.html>

Liberty Hyde Bailey Hortorium. 1976. Hortus third: A concise dictionary of plants cultivated in the United States and Canada. $3^{\text {rd }}$ ed. Macmillan, New York.

McGrew, J. 1998. Solidago (goldenrod), p. 755-757. In: V. Ball (ed.). Ball redbook. $16^{\text {th }}$ ed. Ball Publ., Batavia, Ill.

Miller, P. 1741. The gardener's dictionary. $5^{\text {th }}$ ed. Printed by S. Powell for R. Gunne, Dublin.

Missouri Botanic Garden. 2000. Plant records database. 14 May 2002. <http:// ridgwaydb.mobot.org/HortWeb/ hortsearch.asp >

Nau, J. 1999. Ball culture guide: The encyclopedia of seed germination. $3^{\text {rd }}$ ed. Ball Publ., Batavia, Ill.
Pathfast Publishing. 1999. Flower sales by genera through Dutch auctions 1998 and 1997, International cut flower manual 1999. 19 May 2002. <http://www.pathfastpublishing.com/docs/Summary-Table.htm>

Philosoph-Hadas, S., R. Michaeli, Y. Reuveni, and S. Meir. 1996. Benzyladenine pulsing retards leaf yellowing and improves quality of goldenrod (Solidago canadensis) cut flowers. Postharvest Biol. Technol.9:6573.

Phillips, H.R. 1985. Growing and propagating wild flowers. Univ. N.C.Press, Chapel Hill.

Pors, B. and P.A. Werner. 1989. Individual flowering time in a goldenrod (Solidago canadensis): Field experiment shows genotype more important than environment. Amer. J. Bot. 76(11):1681-1688.

Pratt, Jr., C.R. 1984. The response of Solidago graminifolia and Solidago juncea to nitrogen fertilizer application: Changes in biomass allocation and implications for community structure. Bul. Torrey Bot. Club 111(4):469-478.

Schwabe, W.W. 1986. Solidago, p. 338340. In: A.H. Halevy (ed.). The handbook offlowering. vol. 5. CRC Press, Boca Raton, Fla.

Semple, J.C. 2001. Goldenrods. Univ. Waterloo, Waterloo, Ont., Can. 19 May 2002. <http://www.science.uwaterloo.ca/ biology/jcsemple/goldrod.htm>

Semple, J.C., G.S. Ringius, and J.J. Zhang. 1999. The goldenrods of Ontario: Solidago L. and Euthamia Nutt. 3rd ed. Univ. Waterloo Biol. Ser. 36:190.
Skidmore-Roth, L. 2001. Mosby's handbook of herbs and natural supplements. Mosby, St. Louis.

Thoen, R., S. Jaffee, C. Dolan, and F. Ba. 2002. Equatorial rose: The Kenyan-European cut flower supply chain. 19 May 2002. http://wwwl.worldbank.org/wbiep/ trade/c_papers/Roses2KenyaSupply chain.pdf>

USDA. 2002. USDA National Ornamental Shipping Point Report. Agr. Mktg. Serv., 14 May 2002. <http://www.ams.usda. gov/marketnews.htm>

U.S. Fish and Wildlife Service. 1985a. Endangered and threatened wildlife and plants: Determination of threatened status for Solidago spithamea (Blue Ridge goldenrod). Fed. Reg. 50:12306-12309.

U.S. Fish and Wildlife Service. 1985b. Endangered status for Solidago shortii (Short's goldenrod). Fed. Reg. 50:36085-36089.

U.S. Fish and Wildlife Service. 1985c. Determination of threatened status for Solidago houghtonii (Houghton's Goldenrod). Fed. Reg. 53:27134-27137.

U.S. Fish and Wildlife Service. 1988. Determination of threatened status for Solidago albopilosa (White-haired Goldenrod). Fed. Reg. 53:11612-11615.

Vromen, G. 1998. New airport rules threaten flowering relationship. Organization for the promotion of trade Israel-Netherlands. 19 May 2002. <http://www.optin.nl/optin/ article6.html> 